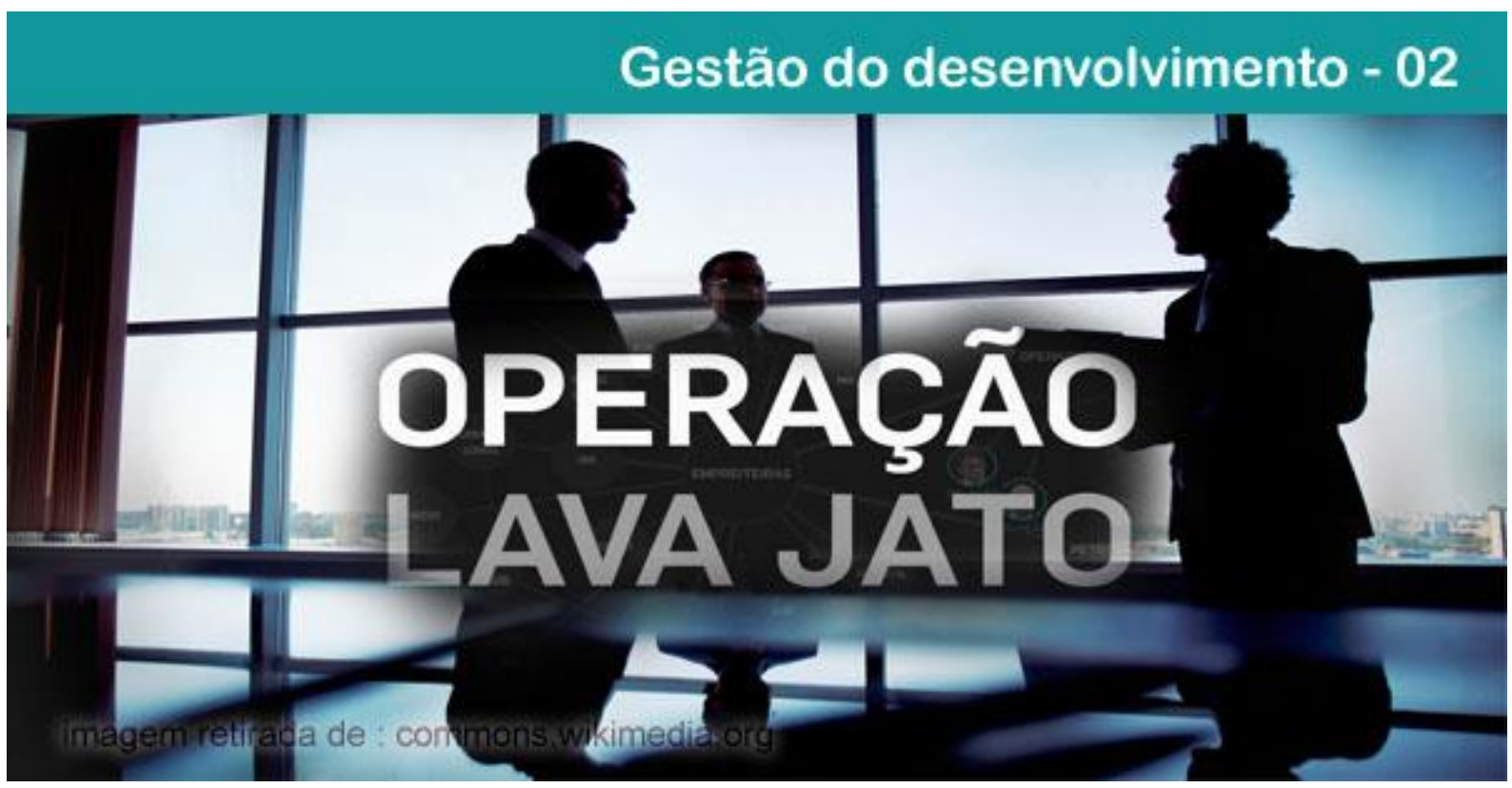

\title{
A (IR)RESPONSABILIDADE SOCIAL CORPORATIVA NO BRASIL: EMPRESAS, PODER E LAÇOS ENTRELAÇADOS
}

\author{
Maria Alice Nunes Costa \\ Professora da Universidade Federal Fluminense (UFF). Cientista Política e Doutora em Planejamento Urbano \\ e Regional.E-mail: alicecosta.rj@uol.com.br.

\section{Elaine Borin} \\ Professora da Universidade do Estado do Rio de Janeiro (UERJ). Doutora em Planejamento Urbano e Regional. \\ E-mail: elaine.borin@ig.com.br.
}

Resumo: Este artigo tem como objetivo analisar as condutas empresariais socialmente irresponsáveis no Brasil. A irresponsabilidade das empresas foi denunciada por meio da "Operação Lava Jato", iniciada em 2014 e ainda em curso no país. O foco deste artigo são as teias tecidas entre as empresas envolvidas, políticos e parlamentares no esquema de corrupção, em especial com grandes empresas empreiteiras, responsáveis pela infraestrutura do Brasil. Elas formavam um cartel para se associar a uma das maiores indústrias petroleiras do mundo, a Petrobras (Petróleo Brasileiro S.A.). Essa operação deflagrou um modus operandi histórico no Brasil, em que demonstra a relação perniciosa entre o público e o privado no Brasil. A análise é baseada em um estudo de caso, com dados empíricos apresentados pelos órgãos federais responsáveis pela Operação Lava Jato, que se encontram disponíveis na internet e na imprensa brasileira. Este estudo analisa, portanto, os dados empíricos e os históricos sobre a natureza do modelo de capitalismo dos laços desenvolvidos no Brasil. Conclui-se que, quando uma sociedade possui uma tradição histórico-cultural permeada por estreitas relações privadas e patrimoniais entre governo e empresas, esse fato impacta negativamente no desempenho econômico e no capital reputacional de empresas e governo, ferindo consequentemente a adoção de um comportamento ético e de responsabilidade social corporativa. Palavras-chave: Condutas empresariais. Capitalismo de laços. Responsabilidade social corporativa.

\section{CORPORATE SOCIAL (IR)RESPONSIBILITY IN BRAZIL: COMPANIES, POWER AND TIES INTERTWINED}

Abstract: This article aims to analyze the socially irresponsible business conduct in Brazil. The irresponsibility of the companies was denounced through the "Operation Lava Jato", begun in 2014 and still in progress in the country. The focus of this article are the webs woven between the companies involved, politicians and

\section{POLÊM!CA | LABORE}

Polêmica - Revista Eletrônica da Uerj - Rua São Francisco Xavier, 524, $1^{\circ}$ andar bloco D, sl.1001 • Tels.: +55 21 2334-4088 / 4087 • http://www.e-publicacoes.uerj.br/index.php/polemica/index http://www.labore.uerj.br • laboreuerj@yahoo.com.br 
parliamentarians in the corruption scheme, especially with large companies contractors, responsible for the infrastructure of Brazil. They formed a cartel to join one of the world's largest oil companies, Petrobras (Petróleo Brasileiro S.A.). This operation triggered a historical modus operandi in Brazil, in which it demonstrates the pernicious relationship between the public and the private in Brazil. The analysis is based on a case study, with empirical data collected by the federal agencies responsible for Operation Lava Jato, which are available on the internet and in the Brazilian press. This case study therefore analyzes empirical and historical data on the nature of the capitalist model of the ties developed in Brazil. It is concluded that, when a society has a historical-cultural tradition permeated by close private and patrimonial relations between government and companies, this fact negatively impacts on the economic performance and reputational capital of companies and government, consequently hurting the adoption of ethical behavior and corporate social responsibility.

Keywords: Business conduct. Capitalism of ties. Corporate social responsibility

\section{Introdução}

Como o filósofo Comte-Sponville (2005) afirmou, a moralidade tornou-se, desde os anos 80 , um tema da moda. Isso não significa necessariamente que pessoas, instituições e empresas tenham se tornado mais virtuosas. Segundo Costa (2011), as empresas, especialmente na década de 1990, têm que enfrentar desafios éticos em relação às dimensões econômica, ambiental e social dos negócios. Elas precisavam se articular com os governos e a sociedade civil através do discurso da responsabilidade social corporativa - RSC, como matriz orientadora estratégica para permanecer em um mercado altamente competitivo e com um estado de regulação social no processo de mudança.

No entanto, a atual crise econômica global mostrou que houve numerosas e significativas fraquezas de organizações internacionais multilaterais no campo da RSC. O fato de as organizações internacionais apenas sensibilizarem as empresas a assumirem um comportamento socialmente responsável é muito pequeno. Acredita-se que seria mais eficaz aplicar sanções a empresas que não atuam de maneira socialmente responsável.

As pressões e restrições das organizações internacionais para a adoção da RSC no mundo foram mediadas por uma contingência de fatores internos em cada país. Dessa forma, essa adoção é resultado do sentimento que o empresariado e suas instituições políticas atribuem a essa estratégia, permeando as "idiossincrasias" das esferas institucional e cultural de cada território nacional e / ou local (COSTA, 2008).

Os movimentos da economia não são automáticos, imunes à ação humana. Como as instituições implementam ações depende de como cada país traduz e interpreta a realidade. A cultura é, portanto, o terreno onde as escolhas subjetivas são fortalecidas ou enfraquecidas.

Tem-se observado nos países periféricos e semiperiféricos do sistema capitalista mundial, particularmente na América Latina, que nem todas as empresas adotam o discurso ou

\section{POLÊM!CA $\mid$ LABORE}

Polêmica - Revista Eletrônica da Uerj - Rua São Francisco Xavier, 524, $1^{\circ}$ andar bloco D, sl.1001 • Tels.: +55 21 2334-4088 / 4087 • http://www.e-publicacoes.uerj.br/index.php/polemica/index http://www.labore.uerj.br • laboreuerj@yahoo.com.br 
a prática da responsabilidade social corporativa. A opção, na maioria das vezes, se concentra no marketing social. É desse modo que observa-se a trajetória do desenvolvimento da estratégia de RSC no Brasil frente ao modus operandi do capitalismo brasileiro tardio. Esse capitalismo desenvolveu-se historicamente através de algumas gramáticas políticas, como o patriarcalismo e o clientelismo (NUNES, 1997).

Essas gramáticas ainda estão presentes no DNA institucional brasileiro. Dessa forma, o capitalismo, tanto no Brasil quanto em outros países da América Latina, trabalha por meio de relações estreitas de vínculos pessoais, familiares e privados entre empresários e funcionários do governo. Esse modo de agir tem um forte impacto na economia e na sociedade, na medida em que corrompe os ideais de bem público.

Este artigo tem o objetivo de analisar as condutas empresariais socialmente irresponsáveis da região Sul-americana, em particular no Brasil. A irresponsabilidade dessas empresas foi denunciada por meio da "Operação Lava Jato", iniciada em 2014 e ainda em curso no Brasil. O objeto deste artigo são as teias tecidas entre as empresas envolvidas, políticos e parlamentares no esquema de corrupção, em especial com grandes empresas empreiteiras, responsáveis pela infraestrutura do Brasil. Elas formavam um cartel para se associar a uma das maiores indústrias petroleiras do mundo, criada em 1953: a Petrobrás (maior empresa estatal petrolífera brasileira), desde longa data.

A Petrobras é uma empresa de capital aberto, cujo acionista majoritário é o Governo do Brasil (União). Com sede no Rio de Janeiro, opera em 25 países, no segmento de energia, prioritariamente nas áreas de exploração, produção, refino, comercialização e transporte de petróleo, gás natural e seus derivados. Por ironia, o seu lema de gestão é: "Uma empresa integrada de energia que atua com responsabilidade social e ambiental"1.

Portanto, serão apresentadas, brevemente, algumas das práticas contraditórias com a política estratégica da responsabilidade social corporativa e apontado o impacto e a dimensão que essas práticas de irresponsabilidade corporativa geram no espaço sul-americano. Ressaltase que esta análise será baseada nas relações empresariais identificadas na "Operação Lava Jato" como uma forma de explicitar uma prática de relações que podem ser consideradas como

\footnotetext{
${ }^{1}$ Petrobras (Petróleo Brasileiro S.A.), 2017. Disponível em: <http://www.petrobras.com.br/pt/sociedade-e-meioambiente/sociedade/politica-de-responsabilidade-social/>. Acesso em: 15 jun. 2017.
}

\section{POLÊM!CA | LABORË}

Polêmica - Revista Eletrônica da Uerj - Rua São Francisco Xavier, 524, $1^{\circ}$ andar bloco D, sl.1001 • Tels.: +55 21 2334-4088 / 4087 • http://www.e-publicacoes.uerj.br/index.php/polemica/index http://www.labore.uerj.br • laboreuerj@yahoo.com.br 
expressão de um capitalismo de laços entre empresas, característico de países da América do Sul.

Para a realização do estudo foi elaborada uma pesquisa documental, com consulta a site do Ministério Público Federal, da Polícia Federal do Brasil e em revista e livros que tratavam desta Operação, buscando recuperar duas categorias que representam a base conceitual do presente artigo: a relação entre responsabilidade social e o modus operandi do capitalismo no espaço Sul-americano, em particular no Brasil. Tal recuperação se constitui em um arcabouço que orienta as preocupações mais concretas relativas às interfaces entre Estado, governos e empresas. A “Operação Lava-Jato" tem representado um fato social que permite questionar o modo como tem se desenvolvido o capitalismo regional e local em tempos recentes, que tem rastro com a sua trajetória histórica colonial e patrimonialista.

\section{A “Operação Lava Jato" no Brasil: os laços entre o estado e as empresas}

A “Operação Lava Jato" é uma investigação em andamento que teve início no dia 17 de março de 2014, conduzida pela Polícia Federal do Brasil. Inicialmente foram mais de cem mandados de busca e apreensão, de prisão temporária, de prisão preventiva e de condução coercitiva, com o objetivo de apurar um esquema de lavagem de dinheiro, de corrupção ativa e passiva, de gestão fraudulenta de câmbio, e de recebimento de vantagem indevida, que já movimentou até agora o valor de $\mathrm{R} \$ 8$ trilhões $^{2}$.

A “Operação Lava Jato” tem esse nome devido a uma investigação da Polícia Federal em um posto de gasolina, em Brasília. O dono deste posto de gasolina enviava dinheiro para fora do Brasil de maneira ilegal. Vários doleiros do esquema usavam o posto para lavarem dinheiro por meio de uma casa de câmbio, que servia como fachada para seu verdadeiro negócio: a lavagem de dinheiro de propina para políticos e agentes públicos. Na primeira fase da operação, policiais atuaram em seis Estados e no Distrito Federal, prendendo 24 pessoas. O doleiro (operador de mercado paralelo ou ilegal de câmbio) Albert Youssef, apontado como um dos mentores do esquema, foi um dos detidos. Diversos outros envolvidos foram presos. O envolvimento de políticos nas denúncias de corrupção levou à abertura de uma Comissão Parlamentar de Inquérito no Senado para investigar as possíveis irregularidades na Petrobras. Albert Youssef decidiu assinar no Ministério Público Federal um acordo de delação premiada.

${ }^{2}$ Caso Lava Jato. Disponível em:<http://lavajato.mpf.mp.br/>. Acesso em: 15 jun. 2017.

\section{POLÊM!CA $\mid$ LABORE}

Polêmica - Revista Eletrônica da Uerj - Rua São Francisco Xavier, 524, $1^{\circ}$ andar bloco D, sl.1001 • Tels.: +55 21 2334-4088 / 4087 • http://www.e-publicacoes.uerj.br/index.php/polemica/index http://www.labore.uerj.br • laboreuerj@yahoo.com.br 
Desde então, as informações fornecidas pelos acusados em troca de benefícios tornaram-se a principal frente da operação. Em maio de 2018 essa Operação já estava na sua $51^{a}$ fase.

A Polícia Federal a considera a maior investigação de corrupção da história do Brasil. De acordo com as delações recebidas pela força-tarefa da Lava Jato, estão envolvidos políticos de vários partidos, empresários de empreiteiras e membros administrativos da empresa estatal petrolífera - Petrobrás - e de outras empresas públicas.

Esta operação foi inspirada em uma realizada na Itália, nos anos 1992-1996, denominada por Operação "Mãos Limpas”. A “Operação Lava Jato” é operada pela Polícia Federal e pelo Ministério Público Federal, que tem como protagonista o Juiz Federal Sérgio Moro, de Curitiba, Paraná.

As investigações estão sendo divididas em várias fases e sem prazo para terminar. Nesse artigo serão apresentadas apenas as três primeiras, por serem importantes para entender o início da relação obscura entre empresas e governo, foco desse trabalho. A primeira fase se concentrou nos crimes financeiros praticados por organizações criminosas lideradas por doleiros. A segunda focou em atos de corrupção e lavagem de dinheiro praticados na empresa Petrobrás, com propinas que inicialmente somaram cerca de $\mathrm{R} \$ 10$ bilhões. Na terceira fase começaram as investigações em outras empresas públicas, como o banco Caixa Econômica Federal e a Eletronuclear.

No início da investigação, foram processadas quatro organizações criminosas lideradas por doleiros. O Ministério Público Federal recolheu provas de um esquema criminoso de corrupção envolvendo a Petrobras. Nesse esquema, grandes empreiteiras, organizadas em cartel e aliadas às empresas e consultorias falsas, pagavam propina para altos executivos da Petrobrás e para outros agentes públicos e partidos políticos. O valor da propina variava de $1 \%$ a $5 \%$ do montante total de contratos bilionários, superfaturados com a estatal, que serviam para as campanhas eleitorais, muitas de forma ilegal, para políticos, envolvidos ou não no esquema, se elegerem. Esse suborno era distribuído por meio de operadores financeiros do esquema, incluindo doleiros investigados na primeira etapa.

A seguir será detalhado como era a participação, no esquema de corrupção, das empresas, dos funcionários da Petrobras, dos operadores financeiros e dos agentes políticos.

As empresas empreiteiras, em um cenário juridicamente lícito concorreriam entre si, em licitações, para firmar contratos com a Petrobras. Como qualquer licitação, há regras e normas

\section{POLÊM!CA $\mid$ LABORE}

Polêmica - Revista Eletrônica da Uerj - Rua São Francisco Xavier, $524,1^{\circ}$ andar bloco D, sl.1001 • Tels.: +55 21 2334-4088 / 4087 • http://www.e-publicacoes.uerj.br/index.php/polemica/index http://www.labore.uerj.br • laboreuerj@yahoo.com.br 
de concorrência pública. A empresa ganhadora da licitação deveria estar em conformidade com esses procedimentos e a obra deveria ter um preço justo para ser contratada pela Petrobras. Contudo, o que ocorria era bem diferente. As empreiteiras formaram um cartel para violar uma concorrência real. Os preços oferecidos à Petrobras eram calculados e ajustados em reuniões secretas, nas quais se definia quem ganharia o contrato e qual seria o preço, inflado em benefício privado e em prejuízo dos cofres da estatal. Esse cartel criado há anos, possuía um "regulamento" para definir como as obras seriam distribuídas. Para disfarçar o crime, o registro escrito da distribuição de obras era feito, por vezes, similar à distribuição de prêmios de um jogo de bingo.

Quanto aos funcionários da Petrobras, as empresas precisavam garantir que apenas as pertencentes do cartel fossem convidadas para as licitações, com isso, alguns funcionários que estavam ligados ao cartel favoreciam essas empresas, restringindo a entrada de outras. Com o apoio de executivos da Petrobras, celebravam aditivos desnecessários e com preços excessivos para eliminar empresas que não pertenciam ao cartel. Foi descoberto que eram feitas negociações diretas com as empresas do cartel de maneira criminosa. Aceleravam contratações, com supressão de etapas relevantes e vazavam informações sigilosas, dentre outras irregularidades.

Os operadores financeiros ou intermediários eram responsáveis não só por intermediar o pagamento da propina, mas especialmente por entregá-la disfarçada de dinheiro limpo aos beneficiários. $\mathrm{O}$ dinheiro ia das empreiteiras até o operador financeiro. Isso acontecia em espécie, por movimentação no exterior, em especial na Suíça, por meio de contratos simulados com empresas de fachada. Num segundo momento, o dinheiro ia do operador financeiro até o beneficiário em espécie, por transferência ao exterior ou mediante pagamento de bens.

Em relação aos agentes políticos, para a Procuradoria Geral da República (PGR), esses agentes, aliados às empreiteiras contratadas pela Petrobras, agiam em associação criminosa, de forma estável, com comunhão de esforços e unidade de desígnios para praticar diversos crimes, dentre os quais corrupção passiva e lavagem de dinheiro. O lobista brasileiro, Fernando Baiano, e o tesoureiro do Partido dos Trabalhadores (PT), João Vacari Neto, atuavam no esquema criminoso como operadores financeiros, em nome de integrantes dos partidos políticos: Partido do Movimento Democrático Brasileiro (PMDB) e do PT. A Figura 1 a seguir, apresenta uma representação gráfica do esquema desenhado pelo Ministério Público Federal, o qual envolve

\section{POLÊM!CA | LABORE}

Polêmica - Revista Eletrônica da Uerj - Rua São Francisco Xavier, $524,1^{\circ}$ andar bloco D, sl.1001 • Tels.: +55 21 2334-4088/4087 • http://www.e-publicacoes.uerj.br/index.php/polemica/index http://www.labore.uerj.br • laboreuerj@yahoo.com.br 
todos os participantes do esquema de corrupção: empresas; funcionários da Petrobras, políticos e operadores financeiros.

Figura - 1

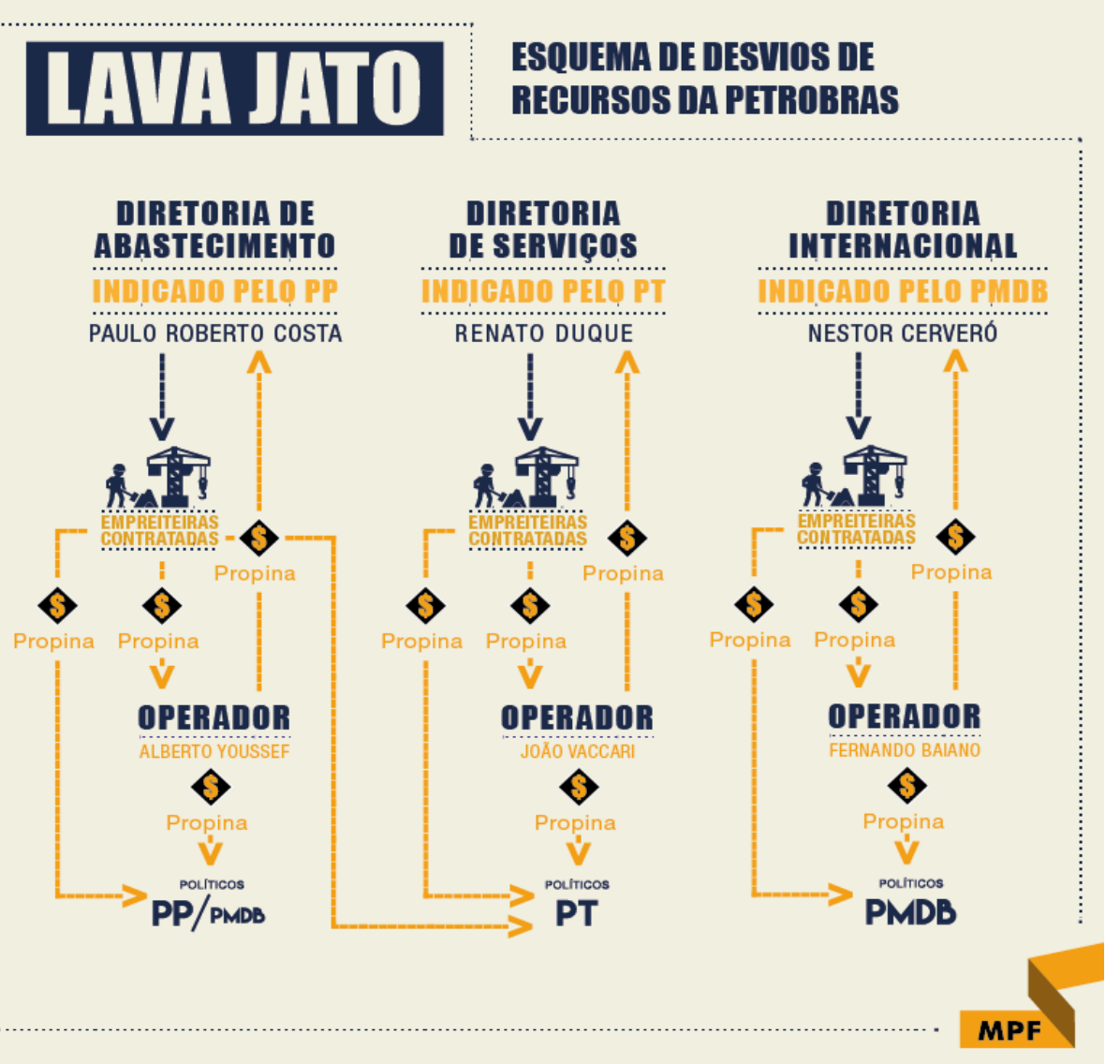

Fonte: Site do Ministério Público Federal (MPF).

A participação das empresas empreiteiras envolvidas na "Lava Jato" na Campanha eleitoral presidencial de 2014 mostrou como os partidos eram financiados para suas campanhas eleitorais. As empresas construtoras doaram mais de 300 milhões de reais. Dos dez maiores doadores, cinco são do ramo da construção. É o caso de empresas ligadas às operações da Petrobras: a OAS; a Andrade Gutierrez; UTC engenharia; Queiroz Galvão; e a maior empreiteira ligada à Petrobras, a Odebrecht, que opera em vários países. O esquema envolveu várias empresas, políticos, partidos e instituições no âmbito governamental.

Em meados de 2015, mediante a Força-Tarefa da Operação Lava-Jato, o Ministério Público Federal e a Superintendência-Geral do Conselho Administrativo de Defesa Econômica - Cade (autarquia federal vinculada ao Ministério da Justiça que tem por objetivo constitutivo

\section{POLÊM!CA $\mid$ LABORE}

Polêmica - Revista Eletrônica da Uerj - Rua São Francisco Xavier, 524, $1^{\circ}$ andar bloco D, sl.1001 • Tels.: +55 21 2334-4088 / 4087 • http://www.e-publicacoes.uerj.br/index.php/polemica/index http://www.labore.uerj.br • laboreuerj@yahoo.com.br 
zelar pela concorrência em todo o território nacional) firmaram acordo de leniência com a empresa Construções e Comércio Camargo Corrêa S/A. Deste acordo, ocorreu a obtenção de informações relevantes, bem como provas referentes ao ilícito de cartelização entre empresas que disputaram licitações públicas promovidas pela Eletronuclear para construção da Usina Angra 3. O ilícito foi delatado no âmbito da Operação Lava-Jato pelo ex-presidente da Camargo Corrêa, que firmou acordo de delação premiada no início do referido ano. Ele afirmou a existência de cartel nas licitações, bem como esclareceu a existência de pagamento de propinas no âmbito da construção da Usina Angra 3 e apresentou informações e provas sobre a existência de cartel das empresas empreiteiras ligadas à Petrobras.

Diante deste cenário, observa-se uma das maiores empresas do Brasil envolvida em um esquema de lavagem de dinheiro ao longo dos últimos 10 anos, aproximadamente. Consequentemente, o mercado brasileiro se vê diante da necessidade de adotar medidas urgentes para tentar minimizar a desconfiança instaurada pelos últimos acontecimentos. No caso da Petrobras, com as denúncias, o preço de suas ações despencou e a captação de recursos para a continuidade de suas atividades ficou praticamente paralisada. Cabe salientar que a Petrobras e algumas das empresas citadas na operação da Polícia Federal possuíam ações negociadas na bolsa de Nova York, pressupondo que cumpria as determinações impostas pela SEC, órgão regulador norte-americano.

No Brasil, o primeiro eixo da política desenvolvimentista foi marcado pela forte interação entre o governo federal e os segmentos da indústria de commodities intensiva em capital (JBS, Friboi, BRF, Vale, Gerdau e Votorantim) e da construção civil (Construtora Odebrecht, Camargo Corrêa, Andrade Gutierrez, Queiroz Galvão e Construtora OAS). Essa política, compreendida como a busca de transformações estruturais, impulsionadas pelo Estado, se vê agora interrompida no Brasil. Teve como objetivo criar e fortalecer os grandes grupos econômicos nacionais por meio de programas especiais de crédito e de participação acionária via atuação do Banco Nacional de Desenvolvimento (BNDES), por meio do apoio a sua internacionalização e por meio das estratégias de investimento da Petrobras, atrelada à exigência de conteúdo nacional para a aquisição de insumos pela estatal.

Atualmente, o Brasil, que antes estava com um crescimento por meio desta política desenvolvimentista, direcionado pelo governo federal, se vê hoje totalmente fragilizado pela

\section{POLÊM!CA $\mid$ LABORE}

Polêmica - Revista Eletrônica da Uerj - Rua São Francisco Xavier, 524, $1^{\circ}$ andar bloco D, sl.1001 • Tels.: +55 21 2334-4088 / 4087 • http://www.e-publicacoes.uerj.br/index.php/polemica/index http://www.labore.uerj.br • laboreuerj@yahoo.com.br 
crise política e econômica diante da deflagração realizada pela operação Lava Jato e aliada à conjunta internacional de baixo dinamismo econômico.

\section{O cartel identificado na operação Lava Jato}

Segundo Lara, Ferreira e Vieira (2015), o cartel constitui um acordo celebrado entre concorrentes em um mercado, com vistas ao aumento dos lucros mediante a adoção de condutas uniformes, principalmente em matéria de preços. O cartel cuja principal finalidade é o aumento do preço dos produtos ou serviços é denominado cartel clássico (hard core cartel) ${ }^{3}$. Na maioria dos casos, os cartéis configuram práticas restritivas horizontais, pois ocorrem em um mesmo mercado relevante.

Ao discorrerem sobre o cartel, Bierman e Fernandez propõem uma comparação dessa prática ao monopólio. Para os autores, um cartel consiste em um grupo de fornecedores que firmaram um acordo explícito para limitar a competição entre eles em benefício mútuo. Um monopólio consiste em um único tomador de decisões, ao passo que um cartel se compõe de uma associação voluntária.

Num conjunto de atividades destinadas à produção de bens de troca, o preço é fixado tendo em vista a quantidade de bens produzidos e a demanda por esses mesmos bens. Mas, ao mesmo tempo, o preço é o instrumento de que se servem as empresas, dentro do mercado, para alterar as condições, para exercerem sua influência sobre as demais e, por vezes, para dominar o mercado. (FONSECA, 2008).

Segundo Hovenkamp (1994), o cartel é um acordo entre empresas que deveriam concorrer entre si. Todavia, o objetivo das sociedades empresariais envolvidas é o de restringir a produção a um determinado nível ou pretender vender a um determinado preço acordado.

Nos estudos da International Competition Network - ICN (2005), os cartéis são considerados as mais graves infrações à concorrência. As autoridades de defesa da concorrência ao redor do mundo têm aumentado seus esforços para combater os cartéis, tanto nacionais quanto internacionais. Diante dos prejuízos ao mercado, os órgãos de concorrência da União Europeia há muitos anos vêm punindo a prática de cartéis e impondo multas pesadas aos infratores.

\footnotetext{
${ }^{3}$ Existem dois tipos de cartel, o clássico e o difuso. A diferença do cartel clássico para o difuso está no fato de o primeiro ter caráter permanente, exigindo alguma forma de institucionalidade, como reuniões periódicas ou princípios de comportamento, por exemplo. Enquanto o segundo tem caráter eventual e não institucionalizado, por exemplo, quando um grupo de empresas se reúnem para acordarem um aumento de preço, muitas vezes em função de um fator externo que as afetou simultaneamente. (GABAN, DOMINGUES, 2012, p. 161).
}

\section{POLÊM!CA $\mid$ LABORE.}

Polêmica - Revista Eletrônica da Uerj - Rua São Francisco Xavier, 524, $1^{\circ}$ andar bloco D, sl.1001 • Tels.: +55 21 2334-4088 / 4087 • http://www.e-publicacoes.uerj.br/index.php/polemica/index http://www.labore.uerj.br • laboreuerj@yahoo.com.br 
Os efeitos maléficos dos cartéis são bem conhecidos. Os consumidores se beneficiam com a redução de preços e melhoria dos produtos decorrentes da concorrência. Quando os concorrentes concordam em abandonar a competição em troca da colusão, os consumidores perdem tais benefícios (ICN, 2005, p. 1). Em outro instrumento, a Comissão Europeia acrescentou que:

\footnotetext{
Um cartel é um grupo de empresas semelhantes que se unem, para controlar os preços ou repartir os mercados e limitar a concorrência. Os membros de um cartel podem contar com a parte do mercado que lhes foi atribuída por acordo, não precisando oferecer novos produtos ou serviços de qualidade a preços competitivos. Consequentemente, os consumidores acabam por pagar mais por menos qualidade (ICN, 2005, p. 2).
}

Para alcançar o êxito, os membros do cartel tendem a agir de modo cauteloso e reservado, o que dificulta a descoberta do acordo pelas autoridades de defesa da concorrência ou a sua comprovação.

Quando se observa o comportamento das empresas arroladas no inquérito da operação Lava Jato, verifica-se, portanto, a formação de um cartel. Segundo os próprios delatores da operação, as práticas concertadas tiveram início em 2004. A divisão dos contratos se dava antes do período do certame licitatório, de maneira que outras empresas não conseguissem competir. O jogo de cartas marcadas já antecipava aos partícipes os vencedores do certame. Do crime de cartel, apurou-se a prática dos crimes de corrupção, lavagem de dinheiro e organização criminosa.

\section{Empresas, função social e responsabilidade social}

Nesta seção será realizada uma breve inflexão sobre a função e a responsabilidade social das empresas, diante do cenário apresentado e deflagrado pela Operação Lava Jato.

O princípio da função social das empresas ingressa pela primeira vez no universo jurídico com a Constituição mexicana de 1917, ao atribuir aos direitos trabalhistas a qualidade de direitos fundamentais, juntamente com as liberdades individuais e os direitos políticos. Contudo, conforme afirma Cavedon (2003), a configuração do Estado contemporâneo, voltado para a proteção dos direitos sociais da Constituição de Weimar, de 1919, influenciou em grande parte as constituições de outros países que passaram a incorporar a noção de Propriedade vinculada a uma Função Social.

\section{POLÊM!CA $\mid$ LABORE}

Polêmica - Revista Eletrônica da Uerj - Rua São Francisco Xavier, $524,1^{\circ}$ andar bloco D, sl.1001 • Tels.: +55 21 2334-4088 / 4087 • http://www.e-publicacoes.uerj.br/index.php/polemica/index http://www.labore.uerj.br • laboreuerj@yahoo.com.br 
Dentre os países que explicitaram, posteriormente, em seus textos constitucionais a Função Social da Propriedade, estão: Brasil, Itália, Espanha, Bolívia, Venezuela, Honduras, Paraguai, El Salvador e Panamá.

Conforme Sundfeld (2011), a Função Social é o conceito jurídico de conteúdo elástico e variável conforme os valores predominantes de determinada sociedade. O termo tem como fundamento a ética, a sociabilidade e a operabilidade. Portanto, a aplicação do princípio da Função Social das empresas consiste em proteger o interesse coletivo, em face da desmesura do direito individual, no intuito de equilibrar as relações entre as partes e garantir um mundo sustentável, onde prevaleçam os direitos humanos.

No Brasil, a expressão "Função Social” da propriedade aparece em algumas de suas várias constituições: nas Constituições de 1934 (art.113), de 1946 (art. 147), de 1967 (art.157, III), de 1969 (art.160, III), sendo recepcionado pela atual Constituição de 1988, nos artigos $5^{\circ}$, XXIII, 170, III, $173, \S 1^{\circ}$, inciso I, 182, § $2^{\circ}, 184$, caput, 185, parágrafo único, 186, caput e incisos do Título VII, "Da Ordem Econômica e Financeira”.

Todavia, cabe ressaltar que embora seja notável a presença do termo "função social" na Carta Constitucional de 1988, o contexto do capitalismo brasileiro, na prática, acaba por provocar uma tensão entre a função social e a nova ordem política e econômica globalizante, tais como a liberdade de concorrência e da iniciativa privada, prescritos na constituição, ao lado da função social.

Desse modo, força-se o Estado brasileiro a recuar gradativamente do seu lugar de executor para fiscalizador e regulador; sobretudo sob o polêmico argumento da superioridade da lógica do mercado em face da ineficiência da gestão estatal.

Vem daí o avassalador processo de desmonte das estruturas públicas pari passu à crescente privatização do patrimônio nacional que, experimentados no Brasil por meio da Reforma do Estado nos anos 1990, executou a reestruturação das empresas societárias e no tipo de relações cruzadas estabelecidas por determinadas empresas com outras empresas privadas e públicas.

A importância da função social das empresas advém do potencial de seus efeitos sobre a sociedade. Podem promover desenvolvimento, gerando riqueza e bem-estar para a coletividade, como o seu contrário também é verdadeiro. Uma empresa mal gerenciada poderá provocar prejuízos sociais incalculáveis e imensuráveis à sociedade. Portanto, a atividade

\section{POLÊM!CA $\mid$ LABORE}

Polêmica - Revista Eletrônica da Uerj - Rua São Francisco Xavier, $524,1^{\circ}$ andar

bloco D, sl.1001 • Tels.: +55 21 2334-4088 / 4087 • http://www.e-publicacoes.uerj.br/index.php/polemica/index http://www.labore.uerj.br • laboreuerj@yahoo.com.br 
empresarial envolve um amplo espectro de interesses de todos que gravitam em torno de seu funcionamento, sejam sócios, empregados, consumidores, comunidade, bem como interesses nacionais e internacionais.

No caso das companhias de natureza pública, consubstanciadas nas chamadas empresas públicas e sociedade de economia mista, o atendimento à função social sofre controle ainda mais imperioso. A liberdade de contratar, por exemplo, encontrará duas limitações peculiares: os empregados deverão ser selecionados por via de concurso público e os contratos comerciais praticados deverão atender a regras específicas de licitações.

Essas empresas se comportam como verdadeiras instituições híbridas no campo da gestão. Ao mesmo tempo em que se pautam na sua função social e desenvolvem atividades de relevante valor social por meio de grandes projetos de responsabilidade social comunitário, também adotam condutas gerenciais no cenário global altamente competitivo, para sobreviverem.

Nessa ambivalência de interesses sociais e econômicos, destaca-se no Brasil a criação da Corregedoria Geral da União (CGU), em 2001, pelo Governo Fernando Henrique Cardoso (1995-2003), com o propósito de integrar vários órgãos do governo que atuam no combate à corrupção, entre eles a Polícia Federal, a Receita Federal e o Ministério Público. Esse órgão foi criado quando se constatou uma diversidade de desvios de verbas da Superintendência de Desenvolvimento da Amazônia. Portanto, essa corregedoria teria como meta agilizar as investigações e dar maior visibilidade sobre as ações do governo de combate à corrupção. Em 2003, esse órgão passou a ser denominado por Controladoria Geral da União, com os mesmos propósitos: pela defesa do patrimônio público, transparência e combate à corrupção.

O principal escopo de toda essa instrumentalidade jurídica pertinente à empresa pública, em última instância, é impor o princípio da função social como norte da empresa, ou seja, assegurar a conduta ética e social evitando atos fraudulentos, obscuros, que atentam contra os direitos coletivos e de interesse nacional.

A responsabilidade social das empresas é corolária do princípio da função social. A ideia dessa responsabilidade das empresas veio sendo debatida de maneira extensiva, desde os anos 1990. A partir de então, tem-se observado a ampliação e a evolução do debate sobre as teorias e terminologias sobre o tema. Algumas teorias combinam diferentes abordagens e usam a mesma terminologia com diferentes significados. É certamente um exemplo de polissemia, na

\section{POLÊM!CA | LABORE}

Polêmica - Revista Eletrônica da Uerj - Rua São Francisco Xavier, 524, $1^{\circ}$ andar bloco D, sl.1001 • Tels.: +55 21 2334-4088 / 4087 • http://www.e-publicacoes.uerj.br/index.php/polemica/index http://www.labore.uerj.br • laboreuerj@yahoo.com.br 
medida em que significa alguma coisa, mas nem sempre significa a mesma coisa para todo mundo. O termo vem carregado por um conjunto de expectativas dirigidas ao público, a partir de conceitos, sentidos, ideologias e entendimentos distintos.

$\mathrm{Na}$ América Latina, muitas organizações empresariais voltadas para a responsabilidade social estão ligadas através de uma rede de relações com a organização empresarial americana BSR (Business Social Responsability). Esta rede foi criada a partir de um Encontro em Miami, Social Venture Network, em 1997, com o intuito de se criar um modelo de responsabilidade social empresarial para ser seguido na América Latina. Tem-se como exemplo o Instituto Ethos no Brasil, criado em 1998, a Aciona Empresarial no Chile (1999), Fundemas em El Salvador (2000); inclui-se aqui também organizações mais antigas como a Mexican Center for Philanthropy (1988) e a Peru 2021 (1994), além de outras organizações similares que estão ativas na Argentina, na Colômbia e Panamá.

Essas organizações têm desenvolvido uma ampla rede com ONGs locais e internacionais, agências governamentais, organizações multilaterais, universidades, centros de pesquisa, fundações filantrópicas americanas através de uma agenda de conferências nacionais e internacionais sobre práticas de responsabilidade social empresarial na América Latina. Na América Latina, pode-se identificar o mesmo contexto: um Estado fraco, a redemocratização e as reformas neoliberais. A implementação de privatizações, reformas econômicas e institucionais com consequências sociais desiguais torna o balanço de poder entre o Estado e as empresas diferente e o setor privado/mercado fica mais poderoso. Nesse sentido, o setor privado, a partir dos anos noventa, passou a se preocupar com a sua legitimidade no cenário de crises, incertezas, baixo crescimento e de aumento das desigualdades sociais. Criou-se para o empresariado oportunidades de sair de seus limites corporativos estreitos para ter uma visão mais assertiva, nacional e universalista (COSTA, 2011).

Contudo, esses fenômenos se organizam de maneira diferente entre os países, a partir de dois fatores primordiais, que se inter-relacionam: 1) pressão e mobilização social, em que as questões sobre a pobreza, a desigualdade, a discriminação, direitos humanos, justiça social emergem ao lado dos altos níveis de desemprego, no cenário do fim dos governos militares nos anos 80 - a sociedade organizada busca novas oportunidades para se organizar e se expressar, além disso, criam-se consumidores mais exigentes; 2) cultura e nova visão e percepção entre as elites empresariais - os empresários são "iluminados" por novas ideias no enfrentamento de

\section{POLÊM!CA | LABORE}

Polêmica - Revista Eletrônica da Uerj - Rua São Francisco Xavier, $524,1^{\circ}$ andar bloco D, sl.1001 • Tels.: +55 21 2334-4088/4087 • http://www.e-publicacoes.uerj.br/index.php/polemica/index http://www.labore.uerj.br • laboreuerj@yahoo.com.br 
realidades práticas e sociais que demandam novas estratégias de inserções em período de transição política e econômica.

É quase impossível imaginar estratégias de combate às escolhas políticas e econômicas que vêm infligindo a defesa pela justiça social e ambiental do sistema mundial e, contraditoriamente, o próprio sistema capitalista. O desrespeito ao equilíbrio econômico, social, humano e ambiental é irracional do ponto de vista das escolhas que acreditam ser pretensamente "racionais" das teorias política e econômica no século XXI.

A contaminação dos fins sociais das empresas por interesses particulares tem sido, sem dúvida, o grande vilão do monopólio da exploração de atividades de interesse nacional pelo poder público ou pela simples atuação do Estado como gestor das grandes empresas nacionais.

Entre as Companhias de Mercado Aberto de grande impacto socioeconômico no Brasil, quiçá, na América Latina, encontra-se a Petrobrás, principal parte da Operação Lava Jato. Cabe destacar que a empresa, desde os anos noventa, atua em vários projetos sociais de responsabilidade social e, em sua política gerencial, anuncia:

\begin{abstract}
Responsabilidade social, para nós, é a forma de gestão integrada, ética e transparente dos nossos negócios e atividades e das nossas relações com todos os públicos de interesse, promovendo os direitos humanos e a cidadania, respeitando a diversidade humana e cultural, não permitindo a discriminação, o trabalho degradante, o trabalho infantil e escravo e contribuindo para o desenvolvimento sustentável e para a redução da desigualdade social. (PETROBRÁS, 2017).
\end{abstract}

\title{
Os laços entre empresas, governo e estado
}

Claus Offe (1984) atentou para a existência de limites do Estado capitalista perante as crises econômicas. Esses limites emanam da ambivalência dos propósitos do Estado. Por um lado, tem como função conciliar dinamicamente os requisitos da acumulação capitalista; por outro, preservar a legitimidade de seu poder, por meio de seu papel enquanto representante dos interesses gerais e comuns da sociedade como um todo. Nesse sentido, a tomada de decisões pelo governo vai se basear na tentativa de estabelecer um equilíbrio dinâmico entre os elementos constitutivos dos interesses da acumulação de capital e dos interesses dos trabalhadores.

Para Offe (1984), o Estado é incapaz de desempenhar funções produtivas necessárias para manter e promover a acumulação; porém, está tentando constantemente reconciliar interesses e legitimidade perante os cidadãos. O Estado capitalista não pode resolver de forma

\section{POLÊM!CA $\mid$ LABORE}

Polêmica - Revista Eletrônica da Uerj - Rua São Francisco Xavier, 524, $1^{\circ}$ andar bloco D, sl.1001 • Tels.: +55 21 2334-4088 / 4087 • http://www.e-publicacoes.uerj.br/index.php/polemica/index http://www.labore.uerj.br • laboreuerj@yahoo.com.br 
permanente as crises econômicas; e, ao mesmo tempo em que é tolhido pelos interesses dos capitais individuais que obstruem sua intervenção, é abalado pelas exigências da classe operária e de outros eleitorados trabalhistas, dos quais depende como fonte de poder político.

São essas contradições que explicam porque as políticas reformistas do Estado capitalista apontam para um modelo cíclico onde não se atinge nenhum ponto de equilíbrio, compromisso ou estabilidade. Prova desse argumento está no fato de que um mesmo evento a depressão europeia no início dos anos 80 - levou a duas opções políticas diferentes: a ascensão de um governo conservador na Alemanha (Kohl) e de um governo socialista na França (Mitterand).

As políticas econômicas e sociais adotadas e desenvolvidas nos países do Sul do sistema capitalista levaram a um desenvolvimento socioeconômico intermédio. Esses países são definidos como países semiperiféricos do sistema de mundo capitalista, conforme Emanuel Wallerstein (2005). Portanto, pode-se afirmar que existe uma variedade de capitalismos (BOHLE, GRESKOVITS, 2009; HALL, SOSKICE, 2001) e que o Brasil, como país semiperiférico deste sistema hegemônico, possui uma coordenação e um modus operandi diferente dos países centrais (SCHNEIDER, 2009; WILLIAMSON, 1995).

Com origem na Coroa portuguesa, o patrimonialismo representaria, na abordagem de Faoro (1958), o traço cultural do Estado brasileiro que perpassaria os contextos históricos e políticos da sociedade. Evidentemente tem se dado não apenas em função do aparelho do estado em si, mas também com intenso protagonismo dos grupos econômicos e empresariais que têm feito do Estado uma instância de atendimento dos seus interesses privados.

Uma extensa literatura brasileira tem analisado historicamente o sistema políticoadministrativo e econômico brasileiro e suas similaridades com o cenário latino-americano. Nesse contexto, observa-se as esferas pública e privada se intercambiando como um modus operandi, onde o Estado tem sido contaminado por interesses privados e particulares, secularizando ou até mesmo ignorando os interesses públicos.

Ao longo do século XX, o capitalismo, dos países da América Latina, passou por alguns estágios. No período que antecede a segunda Grande Guerra, há predominância do modelo agroexportador. No final da década de 1930, é possível identificar os sinais de uma transição para o modelo urbano industrial. No período de 1945 a 1970, predomina o modelo

\section{POLÊM!CA $\mid$ LABORE}

Polêmica - Revista Eletrônica da Uerj - Rua São Francisco Xavier, 524, $1^{\circ}$ andar bloco D, sl.1001 • Tels.: +55 21 2334-4088 / 4087 • http://www.e-publicacoes.uerj.br/index.php/polemica/index http://www.labore.uerj.br • laboreuerj@yahoo.com.br 
desenvolvimentista pautado pela consolidação de políticas de substituição de importações, fortemente fundamentado na teoria da dependência ${ }^{4}$.

Na década de 1970, as políticas desenvolvimentistas sustentadas pelo tripé Estado autoritário, empresa nacional e empresas multinacionais (estrangeiras) foram fortemente desestruturadas pelos choques de petróleo (1973 e 1979) e pelo fim do sistema de Brettom Woods. Na década de 1980, as economias latino-americanas foram marcadas por desequilíbrios macroeconômicos (forte crescimento da dívida externa, hiperinflação e baixo crescimento da atividade econômica).

A partir da década 1990, os países latino-americanos promoveram um intenso processo de privatização de setores considerados estratégicos, como telecomunicações, rodovias, transportes, portos e energia. Companhias estatais foram entregues às mãos de setores privados nacionais e internacionais. Esse processo foi influenciado pelo chamado Consenso de Washington e representa uma ruptura do modelo desenvolvimentista que caracterizava o capitalismo desses países. Entretanto, as privatizações e a abertura dos mercados não romperam com as características das relações patrimonialistas entre o Estado e as empresas privadas.

Portanto, tratando-se do desenvolvimento econômico brasileiro, sob a dinâmica agrícola ou industrial, as ações e interlaces entre os governos e empresas (e atores privados) sempre estiveram presentes, tendo o Estado, sobretudo, como agente central no processo de atendimento dos interesses das elites locais e das instâncias governamentais, independente do cenário político vigente.

Com o processo de industrialização no Brasil na Era Vargas (1930-1945) ${ }^{5}$, o insulamento burocrático permitiu a existência de "anéis burocráticos" (CARDOSO, 1970), tipicamente baseados em trocas personalistas. Esses "anéis" constituíam ligações de

\footnotetext{
4 “A Teoria da Dependência surgiu no quadro histórico latino-americano do início dos anos 1960, como uma tentativa de explicar o desenvolvimento sócio-econômico na região, em especial a partir de sua fase de industrialização, iniciada entre as décadas de 1930 e 1940. Em termos de corrente teórica, a Teoria da Dependência se propunha a tentar entender a reprodução do sistema capitalista de produção na periferia, enquanto um sistema que criava e ampliava diferenciações em termos políticos, econômicos e sociais entre países e regiões, de forma que a economia de alguns países era condicionada pelo desenvolvimento e expansão de outras". (DUARTE, F.; GRACIOLLI, J., 2018).

${ }^{5}$ Era Vargas é o nome que se dá ao período em que Getúlio Vargas governou o Brasil por 15 anos, de forma contínua (de 1930 a 1945 e 1951-1954). Esse período foi um marco na história brasileira, em razão das inúmeras alterações que Getúlio Vargas fez no país, tanto sociais quanto econômicas, até mesmo de forma ditatorial consoante com a o ideário totalitarista da época. Com o fim da Segunda Guerra Mundial e a vitória dos aliados, Getúlio Vargas renuncia por representar ideários vencidos e, depois, retorna por maioria do voto popular em 1951, criando a Petrobras em 1953. Em agosto de 1954, Vargas, suicida-se devido a graves pressões políticas e econômicas nacionais e internacionais. (SÓ HISTÓRIA - ERA VARGAS, 2017).
}

\section{POLÊM!CA | LABORE}

Polêmica - Revista Eletrônica da Uerj - Rua São Francisco Xavier, 524, $1^{\circ}$ andar bloco D, sl.1001 • Tels.: +55 21 2334-4088/4087 • http://www.e-publicacoes.uerj.br/index.php/polemica/index http://www.labore.uerj.br • laboreuerj@yahoo.com.br 
negociações entre o Estado e os interesses das elites empresariais. Essas negociações não se faziam apenas sob a pressão de grupos genuínos e autônomos; e sim, fazendo parte do próprio aparato estatal, normalmente sob a liderança de um funcionário do Estado, em especial um tecnocrata.

Nesse contexto, a relação estabelecida entre o Estado e o empresariado desenvolvia-se através de múltiplos canais de acesso às diferentes instâncias de regulação econômica. Esses canais incluíam contatos híbridos (pessoais e institucionais) que ocorriam por meio das organizações corporativas de empresários, formando alianças que se estabeleciam entre representantes do setor privado e os burocratas responsáveis pelas agências setoriais do Estado.

Entretanto, com o processo de redemocratização nos anos 1980/1990, urge refletir sobre quais seriam as novas configurações do desenvolvimento industrial e/ou econômico nacional no que concerne ao papel e as relações dos segmentos governamentais e empresariais.

Tal processo tem se dado, por exemplo, com a participação do BNDES e dos fundos de pensões em diversos segmentos empresariais e, evidentemente, combinando interesses setoriais e políticos. A atual dinâmica das relações entre estado e empresas por meio do BNDES também tem resultado, conforme Lazzarini (2011), em uma maior concentração de acionistas e uma consequente redução dos níveis de competitividade nas licitações para projetos governamentais, podendo se desdobrar também em uma inibição de novos concorrentes e possíveis empreendedores.

Fenômeno, talvez mais sintomático e escuso, é o que tem sido deflagrado pela Operação Lava-Jato, em que o financiamento empresarial dos partidos políticos em campanhas eleitorais revelou, em verdade, uma teia ilícita de ações de ambos agentes, comprometendo, assim, os princípios morais e éticos considerados essenciais da função social das empresas, em um contexto democrático e moderno, entre eles: a transparência e a impessoalidade dos negócios e da coisa pública.

Sob o signo da noção de capitalismo de laços, Lazzarini (2011) aponta uma diferente e paradoxal configuração nas relações entre Estado e empresas no Brasil, a partir do período pósprivatização. O processo de privatização reconfigura a participação do Estado na economia, mas não elimina o poder do Governo como indutor das estratégias de mercado. Por sua vez, os agentes privados se aproximam do Governo oferecendo apoio e defendendo políticas que beneficiem seus próprios interesses.

\section{POLÊM!CA | LABORE}

Polêmica - Revista Eletrônica da Uerj - Rua São Francisco Xavier, $524,1^{\circ}$ andar bloco D, sl.1001 • Tels.: +55 21 2334-4088/4087 • http://www.e-publicacoes.uerj.br/index.php/polemica/index http://www.labore.uerj.br • laboreuerj@yahoo.com.br 
$\mathrm{Na}$ realidade o autor retrata a tradição sociológica acerca das análises do Estado brasileiro e suas relações com o mercado e com a sociedade, já analisadas por autores como Sérgio Buarque de Holanda, Raimundo Faoro, Vitor Nunes Leal, Maria Isaura Pereira de Queiroz e Bresser-Pereira, sob o signo das relações entre público e privado.

A tese de Lazzarini se assenta na constatação de que o processo de privatização das empresas estatais, levado a cabo nas décadas finais do século passado, resultou em um redesenho das relações entre o Estado e o setor privado. Os consórcios mistos (capital privado e capital estatal) instituídos para viabilizar o processo de privatização criam uma relação societária entre Estado e firmas privadas. $\mathrm{O}$ autor destaca que a viabilização de recursos via BNDES e fundos públicos para formação dos consórcios mistos foi excedida, assim fortalecendo a influência do Estado sobre decisões estratégicas que deveriam ser exclusivas do mercado.

Essa dinâmica entre Governo e a iniciativa privada resulta em uma espécie de simbiose, onde empresas e grupos privados se aproximam do Estado para obterem facilidades de financiamento e vantagens competitivas, enquanto o Governo se beneficia recebendo o apoio empresarial às diretrizes da política pública e recebendo o financiamento para campanha política. Segundo Lazzarini, esse emaranhado de contatos, alianças e estratégias de apoio gravitando em torno de interesses políticos e econômicos é o que ele denomina de capitalismo de laços (LAZZARINI, 2011, p. 3).

Esse fenômeno sócio-político-econômico tem uma grande expansão nos anos 1990, desde o governo Collor, com a implementação da política industrial e de comércio exterior direcionada para liberalização do comércio, restruturação competitiva e do Plano Nacional de Desestatização (PND). E mais tarde se intensificou, apesar das cores ideológicas e doutrinárias diferentes, nas gestões posteriores de Fernando Henrique Cardoso (1995/2002), Lula (2003/2010) e Dilma Roussef (2011/2016).

Durante o governo Lula, foi lançado o Programa de Desenvolvimento Produtivo (PDP), política industrial que visava fortalecer as empresas nacionais e transformá-las em players Globais. Programa que ficou conhecido como política de "campeões nacionais" e teve uma ação ativa do BNDES. A nova política, então, solidifica as relações entre Governo e empresas estabelecidas nos anos de 1990.

\section{POLÊM!CA $\mid$ LABORE}

Polêmica - Revista Eletrônica da Uerj - Rua São Francisco Xavier, 524, $1^{\circ}$ andar bloco D, sl.1001 • Tels.: +55 21 2334-4088 / 4087 • http://www.e-publicacoes.uerj.br/index.php/polemica/index http://www.labore.uerj.br • laboreuerj@yahoo.com.br 
O fortalecimento dos laços pode ser observado pelo crescimento dos aportes financeiros realizados pelo BNDES que, em 2003, realizou projetos de financiamento de $\mathrm{R} \$ 33$ bilhões e, em 2014, desembolsou R \$ 187 bilhões. Entre as empresas escolhidas como "campeões nacionais" destaca-se o frigorífico JBS, que recebeu entre 2005 e 2015 um aporte financeiro (financiamento direto e compra de ações) de mais de 10 bilhões de reais - em 2015 o BNDESPar (Subsidiária do BNDES que funciona como um fundo de investimento) possuía 20,4\% das ações da JBS. O BNDESPar também possuía em 2015, entre outras ações, 29,10\% das ações da Fibria (indústria de papel e celulose); 28,2\% das ações da Tupy (siderurgia e metalurgia); 10,37\% ações da Petrobrás e 11,86\% das ações da Eletrobrás ${ }^{6}$ (BNDES, 2015).

O BNDES atua como elo fundamental das relações entre o Governo e o Mercado. Ressalta-se que na última eleição para presidente, ocorrida em 2014, a empresa que mais doou recursos para campanha política presidencial foi o frigorífico JBS (366 milhões de reais). Outra importante doadora nas eleições de 2014 foi a organização Odebrecht (107 milhões de reais) ${ }^{7}$, que entre os anos de 2007 e 2015, recebeu financiamento de 8,9 bilhões de dólares do BNDES para obras no exterior.

O que essa trajetória pode trazer de reflexão é: como o processo de escolha de uma determinada empresa privada para participar, por exemplo, de um empreendimento governamental, está sendo contaminado pelas linhas de interesses fortemente estabelecidas entre os entes em questão, resultando em um cenário nebuloso entre interesses públicos e privados, individuais e coletivos, hoje, no Brasil, no século XXI?

A resposta parece estar na história recente do continente latino-americano e, portanto, não só no Brasil, em que os países dessa região foram varridos pela chamada "onda neoliberal", expressão ideológica que se revelava na orientação do Consenso de Washington, pautada na privatização, na abertura comercial e na redução dos gastos governamentais e dos direitos trabalhistas.

\section{Considerações finais}

A vocação natural das empresas é gerar dividendos para investidores e acionistas, contribuir para o desenvolvimento econômico, criar empregos e fornecer bens e serviços ao

\footnotetext{
${ }^{6}$ Dados dos relatórios do BNDES, 2013, 2014, 2015.

${ }^{7}$ Dados do Tribunal Superior Eleitoral (TSE).
}

\section{POLÊM!CA $\mid$ LABORË}

Polêmica - Revista Eletrônica da Uerj - Rua São Francisco Xavier, 524, $1^{\circ}$ andar bloco D, sl.1001 • Tels.: +55 21 2334-4088 / 4087 • http://www.e-publicacoes.uerj.br/index.php/polemica/index http://www.labore.uerj.br • laboreuerj@yahoo.com.br 
mercado. Nesta fórmula clássica, espera-se que as empresas, na consecução de suas atividades, cumpram com as exigências legais de pagamento de impostos e benefícios trabalhistas, evitem práticas de corrupção e suborno e mantenham auditoria transparente e responsável de seus lucros.

Contudo, o que é observado no Brasil é inversamente contrário. Todas as empresas envolvidas no esquema de corrupção têm em seu sítio eletrônico que possuem uma política de responsabilidade social. É mais uma farsa. Além disso, o que está sendo deflagrado não está acontecendo só atualmente. Vem de longa data. Não é responsabilidade de apenas um partido político, pois a investigação traz vários envolvidos no esquema. O patrimonialismo, como mostrou Faoro (1958), já está instaurado em nossas instituições. Empresas sempre estiveram entrelaçadas com o Estado, agindo de maneira inescrupulosa. O período da ideia da responsabilidade social no Brasil, que se expandiu nos anos 1990, fracassou. Será necessário esperar outras gerações para que algo se transforme em uma real responsabilidade ética.

Na América Latina, em particular no Brasil, a redemocratização gerou a expectativa de que a gestão social seria mais democrática e mais eficiente e elevaria os níveis de bem-estar da população. Contudo, passados 30 anos, há ainda muita desigualdade social e de renda na região, apesar de alguns avanços e retrocessos, na medida em que essa desigualdade na América Latina parece ser atávica e estrutural.

Enfim, não existe apenas um capitalismo cosmológico. Apesar do sistema ser capitalista desde a metade do século XVIII, existe uma variedade de tipologias e diferentes maneiras de coordenação deste capitalismo, seja pelo Estado, pelo Mercado ou de forma híbrida. Portanto, o sistema capitalista se desenvolve em cada região por diversas nuances. Este artigo interpreta como opera o capitalismo da América do Sul, em particular o do Brasil, devido as suas trajetórias históricas, que carrega em seu DNA o colonialismo.

Nessa trajetória histórica, são dados sentidos diferentes ao capital. O valor dado ao capital público ou à coisa pública, por exemplo, se refere à percepção cultural. Essa percepção é apenas um olhar, uma perspectiva, um ponto de vista gerado por heranças culturais colonialistas. Para muitos o dinheiro é o vil metal. Tanto no âmbito privado quanto público, lida-se com o dinheiro da maneira que foi aprendido culturalmente. No Brasil, ainda confundese e mistura-se o público com o privado. O público é meu ou é de ninguém. E assim, indivíduos,

\section{POLÊM!CA | LABORË}

Polêmica - Revista Eletrônica da Uerj - Rua São Francisco Xavier, $524,1^{\circ}$ andar bloco D, sl.1001 • Tels.: +55 21 2334-4088 / 4087 • http://www.e-publicacoes.uerj.br/index.php/polemica/index http://www.labore.uerj.br • laboreuerj@yahoo.com.br 
cidadãos, governos e empresas vão lidando com o capital público da maneira que melhor lhe convier.

Qual o valor do dinheiro privado e do público? O valor dele se refere ao valor da troca daquilo que pode-se fazer com ele. Quando a coisa é pública, a moeda de troca é realizada de inúmeras maneiras. Muitos brasileiros não sabem de onde vem o dinheiro que financia a saúde, a Educação, as obras públicas. Não sabem que a verba pública é o dinheiro fruto do trabalho, dos cidadãos contribuintes que esperam que a coisa pública chegue a todos, por meio de equipamentos coletivos de qualidade e eficiência.

A responsabilidade social corporativa (RSE) está intrinsecamente relacionada à trajetória histórica e cultural de uma dada sociedade. A cultura é muito importante no modo operante de como as instituições funcionam. A sociedade brasileira está aprendendo, junto com a democracia, que ser honesto, solidário e cooperativo pode maximizar os interesses individuais e coletivos. Mas a estrada é longa, porque qualquer mudança cultural é geracional.

Por outro lado, todo esse movimento contra a corrupção no Brasil deu uma esperança de que as instituições possam mudar. A impunidade parece estar com os dias contados. No entanto, é necessário ir ao cerne da moral e da cultura para que se transforme a mentalidade de maneira genuína. Desta forma, espera-se que a crise política e econômica sirva de lição para todos: cidadãos inconscientes, governantes corruptos e empresas irresponsáveis.

\section{Referências}

BIERMAN, H. Scott; FERNANDEZ, Luiz. Teoria dos Jogos. Tradução de: Arlete Simille Marques. 2. ed. São Paulo: Pearson Prentice Hall, 2011.

BOHLE, D.; GRESKOVITS, B. Varieties of Capitalism and Capitalism «tout court». European jornal of sociology, 50(03), p. 355-386, 2009.

BNDES, Banco Nacional de Desenvolvimento Econômico e Social. Relatório Anual, 2013.

Relatório Anual, 2014.

Relatório Anual, 2015.

BOITO JR., A. Governos Lula: a nova burguesia nacional no poder. In: BOITO JR., A; GALVÃO, A. (Orgs.). Política e classes sociais no Brasil dos anos 2000. São Paulo: Alameda Casa Editorial, 2012.

CARDOSO, Fernando Henrique; FALETTO, Enzo. Dependência e Desenvolvimento na América Latina: Ensaio de Interpretação Sociológica. 7. ed. Rio de Janeiro: Editora LTC, 1970.

\section{POLÊM!CA | LABORE}

Polêmica - Revista Eletrônica da Uerj - Rua São Francisco Xavier, 524, $1^{\circ}$ andar bloco D, sl.1001 • Tels.: +55 21 2334-4088 / 4087 • http://www.e-publicacoes.uerj.br/index.php/polemica/index http://www.labore.uerj.br • laboreuerj@yahoo.com.br 
CAVEDON, Fernanda de Salles. Função social e ambiental da propriedade. Florianópolis: Momento Atual, 2003.

COMTE-SPONVILLE, André. O Capitalismo é moral?. Rio de Janeiro: Ed. Martins Fontes, 2005.

CASO Lava Jato. Disponível em: <http://lavajato.mpf.mp.br/>. Acesso em: 15 jun. 2017.

COSTA, Maria Alice Nunes. Os padrões da ação coletiva de responsabilidade e solidariedade social do empresariado português: uma interface com o brasil. Oficina CES (Centro de Estudos Sociais), n. 300. Coimbra: CES, Universidade de Coimbra, 2008.

Teias e Tramas da Responsabilidade Social. Rio de Janeiro: Editora Apicuri, 2011.

DUARTE, Pedro Henrique E.; GRACIOLLI, Edilson José. A Teoria da Dependência: interpretações sobre o (SUB)desenvolvimento na América Latina. Disponível em:

<http://www.unicamp.br/cemarx/anais_v_coloquio_arquivos/arquivos/comunicacoes/gt3/sessao4/Pedro_Duarte. pdf $>$. Acesso em: 10 mai. 2018.

SÓ HISTÓRIA - ERA VARGAS. Disponível em: <https://www.sohistoria.com.br/ef2/eravargas/>. Acesso em: 15 jun. 2017.

FAORO, Raymundo. Os Donos do Poder - formação do patronato político brasileiro. Porto Alegre: Editora Globo, 1958.

FONSECA, João Bosco Leopoldino da. O cartel: doutrina e estudo de casos. Belo Horizonte: Mandamentos, 2008.

FONTINI, Paulo Salvador. Função Social da Companhia: Limitações do Poder de Controle. In: ADAMEK, Marcelo Vieira Von (Org.). Temas de Direito Societário e Empresarial contemporâneos. 1. ed. São Paulo: Malheiros, 2011.

GABAN, Eduardo Molan; DOMINGUES, Juliana Oliveira. Direito Antitruste. 3. ed. São Paulo: Saraiva, 2012.

HALL, P. A.; SOSKICE, D. (Eds.). Varieties of capitalism: The institutional foundations of comparative advantage. OUP Oxford, 2001.

HOLANDA, Sergio Buarque de. Raízes do Brasil. São Paulo: Companhia das letras, 1995.

HOVENKAMP, Hebert. Federal Antitrust Policy: The law of competition and its practices. St. Paul, MINN: West Publish, 1994.

ICN - International Competition Network. Building blocks for effective anti-cartel regimes. Defining Hard Core Cartel Conduct, effective institutions and effective penalties. Luxembourg: Office for Official Publications of the Euopean Communities, 2005.

JORNAL ESTADO DE SÃO PAULO. Disponível em:<http://politica.estadao.com.br/noticias/geral,doacoes-decampanha-somam-r-1-bi-das-quais-metade-vem-de-19-empresas-imp-,1560289>. Acesso em: 10 jun. 2017.

JORNAL ESTADO DE SÃO PAULO. Disponível em:<http://politica.estadao.com.br/noticias/geral,total-depropinas>. Acesso em: 10 jun. 2017.

JORNAL GAZETA DO POVO. Disponível em: <http://www.gazetadopovo.com.br/vida-publica/delatores-dalava-jato>. Acesso em: 10 jun. 2017.

\section{POLÊM!CA $\mid$ LABORE}

Polêmica - Revista Eletrônica da Uerj - Rua São Francisco Xavier, 524, $1^{\circ}$ andar bloco D, sl.1001 • Tels.: +55 21 2334-4088 / 4087 • http://www.e-publicacoes.uerj.br/index.php/polemica/index http://www.labore.uerj.br • laboreuerj@yahoo.com.br 
JORNAL ZH NOTÍCIAS - online. Disponível em: <http://zh.clicrbs.com.br/rs/noticias/noticia/2016/05/valorda-indenizacao-da-andrade-gutierrez-e-quatro-vezes-o-que-pagou-em-propina-5797136.html\#>. Acesso em: 10 jun. 2017.

LARA, Fabiano Teodoro de Resende; FERREIRA, Gustavo Assed; VIEIRA, Susana Camargo. Direito, Economia e Desenvolvimento Sustentável. In: XXVI CONGRESSO NACIONAL DO CONPEDI UFMG/FUMEC/DOM HELDER CÂMARA. Anais... Conselho Nacional de Pesquisa e Pós-Graduação em Direito. 2015

LAZZARINI, S. G. Capitalismo de laços. Os donos do Brasil e suas conexões. Rio de Janeiro: Elsevier, 2011.

LEAL, V. N. Coronelismo, enxada e voto. São Paulo: Editora Companhia das Letras, 2012.

NETTO, Vladimir. Lava Jato. Rio de Janeiro: Ed. Primeira Pessoa, 2016.

NUNES, Edson. A Gramática Política do Brasil. Rio de Janeiro e Brasília: Zahar Eds. e ENAP, 1997.

PEREIRA, L. C. B. Estado e subdesenvolvimento industrializado: esboço de uma economia política periférica. São Paulo: Editora Brasiliense, 1977.

PETROBRAS (Petróleo Brasileiro S.A.). Disponível em: <http://www.petrobras.com.br/pt/sociedade-e-meioambiente/sociedade/politica-de-responsabilidade-social/>. Acesso em: 15 jun. 2017.

PORTAL EBC Agência Brasil - online. Disponível em: <http://www.ebc.com.br/noticias/2015/10/propinasinvestigadas-pela-lava-jato-chegam-r-10-bilhoes-diz-procurador>. Acesso em: 15 de jun. 2017.

OFFE, Claus. Problemas estruturais do estado capitalista. Rio de Janeiro: Ed. Tempo Brasileiro, 1984.

QUEIROZ, M. I. P. D. O messianismo no Brasil e no mundo. São Paulo: Editora Alfa Omega, 1977.

SCHNEIDER, B. R. Hierarchical market economies and varieties of capitalism in Latin America. Journal of Latin American Studies, 41(03), p. 553-575, 2009.

SUNDFELD, Carlos Ari. Fundamentos do Direito Público. 4. ed. São Paulo: Malheiros Editores, 2011.

WALLERSTEIN, Immanuel. World systems analysis: an introduction. Durham: Duke University, 2005.

WILLIAMSON, O. E. (1995). Hierarchies, markets and power in the economy: an economic perspective. Industrial and corporate change, 4(1), 21-49, 19.

Recebido em: 23/10/2017.

Aceito em: 30/01/2018.

\section{POLÊM!CA $\mid$ LABORE}

Polêmica - Revista Eletrônica da Uerj - Rua São Francisco Xavier, 524, $1^{\circ}$ andar bloco D, sl.1001 • Tels.: +55 21 2334-4088 / 4087 • http://www.e-publicacoes.uerj.br/index.php/polemica/index http://www.labore.uerj.br • laboreuerj@yahoo.com.br 